\title{
The effect of place of residence and lifestyle on vitamin D deficiency in pregnancy: Comparison of eastern and western parts of Turkey
}

\author{
Esra Bahar Gür ${ }^{1}$, Gülüzar Arzu Turan¹, Sümeyra Tatar' ${ }^{1}$ Ayşe Gökduman², Muammer Karadeniz ${ }^{3}$, Gülnaz Çelik \\ Mine Genç ${ }^{1}$, Serkan Güçlü ${ }^{1}$ \\ 'Department of Obstetrics and Gynecology, Sifa University Faculty of Medicine, Izmir, Turkey \\ ${ }^{2}$ Department of Biochemistry, Sifa University Faculty of Medicine, Izmir, Turkey \\ ${ }^{3}$ Department of Endocrinology, Shifa University Faculty of Medicine, Izmir, Turkey \\ ${ }^{4}$ Depertment of Biochemistry, Sifa Hospital, Erzurum, Turkey
}

\section{Abstract}

Objective: The aim of this study was to determine the prevalence and the predictive factors of vitamin D deficiency in pregnancy and the compliance with "The National Vitamin D Support Program" at Turkey's easternmost and westernmost provinces.

Material and Methods: Lifestyles of women at 24-28 weeks of pregnancy were assessed using a questionnaire form, and serum 25-hydroxyvitamin D3 (25(OH)D3) levels were measured.

Results: Vitamin D deficiency ( $\leq 20 \mathrm{ng} / \mathrm{mL}$ ) in pregnant women had a prevalence of $27.8 \%$ in İzmir and $76.3 \%$ in Erzurum. The compliance of "The National Vitamin D Support Program" was 8\% in İzmir and 32.6\% in Erzurum. Clothing style, fish consumption, seaside holiday duration, and $1200 \mathrm{IU} /$ day vitamin D replacement had an effect on $25(\mathrm{OH}) \mathrm{D}_{3}$ levels in pregnant subjects in Izmir, whereas only holiday duration and 1200 $\mathrm{IU} /$ day vitamin D replacement affected $25(\mathrm{OH}) \mathrm{D}_{3}$ levels in Erzurum. However, when a threshold for 25(OH)D3 level was considered $\geq 32 \mathrm{ng} /$ $\mathrm{mL}$, lifestyles did not affect $25(\mathrm{OH}) \mathrm{D}_{3}$ level.

Conclusion: The effect of lifestyle on $25(\mathrm{OH}) \mathrm{D}_{3}$ level in pregnancy is limited, especially in cold regions. We recommended increasing the compliance with "The National Vitamin D Support Program" at the follow-up of all pregnant women, irrespective of region and season.

(J Turk Ger Gynecol Assoc 2014; 15: 149-55)

Key words: Pregnancy, vitamin D deficiency, vitamin D replacement, lifestyle, place of residence

Received: 15 April, 2014

Accepted: 09 July, 2014

\section{Introduction}

Vitamin D is a cholesterol derivative steroid hormone that, unlike other vitamins, can be synthesized in the human body. Apart from its known role in calcium metabolism, it has important additional roles in many cellular events by virtue of its autocrine and paracrine effects. It leads to anti-inflammatory and anti-infective responses and regulates cellular proliferation, differentiation, and insulin synthesis (1, 2). Recent studies have shown that vitamin $\mathrm{D}$ has an important role in both healthy pregnancy processes and long-term health of offspring. Recent evidence has suggested that vitamin D has an association with multifactorial diseases of pregnancy, such as bacterial vaginosis, preterm birth, gestational diabetes, and preeclampsia (3-5). In addition, some epidemiologic studies reported that there might be a relationship between allergic diseases, asthma, diabetes mellitus type 1, schizophrenia, and autism and maternal vitamin D deficiency (6-8).
The prevalence of vitamin D deficiency in pregnancy is high all over the word. Classically, conditions, such as a low socioeconomic level, being of African or Latin American descent, obesity, dark skin color, wearing covering clothing, living in northern latitudes, and taking no vitamin D supplements, are known to be associated with vitamin D deficiency. However, high vitamin D deficiency rates have recently been detected in people not usually considered to be 'at risk': with a lighter skin color, have a holiday for a long time, have a higher socioeconomic level, living from sun-drenched, torrid zones, and those believed to have adequate sun exposure (9-11).

The best indicator of vitamin D status is serum 25-hydroxyvitamin D3 $\left(25(\mathrm{OH}) \mathrm{D}_{3}\right)$ concentration, because it reflects both dietary intake from vitamin $\mathrm{D}$ and cutaneous synthesis of vitamin D. However, there is no absolute consensus as to what a normal range for $25(\mathrm{OH}) \mathrm{D}_{3}$ in pregnancy should be. Most authors agree that severe vitamin $\mathrm{D}$ deficiency should be defined by a $25(\mathrm{OH}) \mathrm{D}_{3}$ concentration $\leq 10 \mathrm{ng} / \mathrm{mL}(\leq 25$ 
$\mathrm{nmol} / \mathrm{L})$ and mild vitamin $\mathrm{D}$ deficiency by a $25(\mathrm{OH}) \mathrm{D}_{3}$ concentration 10-20 ng/mL (25-50 nmol/L); but, recent evidence suggests that the optimal serum $25(\mathrm{OH}) \mathrm{D}_{3}$ levels may be even higher than $>32 \mathrm{ng} / \mathrm{mL}$ (>80 nmol/L) (4).

Routine screening for vitamin D deficiency in pregnancy is not considered a cost-effective option. However, many health organizations recommend vitamin D supplementation during pregnancy. But, these issues, such as if vitamin D replacement will be given to all pregnant women or only to high-risk pregnant women, regional and seasonal differences, and the effective and safe dose of vitamin D in pregnancy, are still not clear, and further research is needed concerning these issues.

In the present study, we aimed to a) examine the prevalence of vitamin D deficiency in pregnancy at two extreme geographical points of Turkey; b) examine the effect of different geographical locations in the same latitudes and different lifestyles in the same ethnic origin to vitamin D deficiency prevalence; c) examine the compliance with "The National Vitamin D Support Program for Pregnancy;" and d) inform on future screening and/ or supplementation strategies.

\section{Material and Methods}

İzmir and Erzurum are very distinct provinces of Turkey with respect to both geographical and climatic conditions and social life. They are located in similar latitudes (39.55 North and 38.25 North). İzmir lies on the westernmost point of Turkey (27.0 East). It is located on the Aegean Sea coast and has an altitude of $2 \mathrm{~m}$. According to the Turkish Directorate of Meteorology, the average temperature in the study period was $22.6^{\circ} \mathrm{C}$ daily. Uncovered clothing is common among women. Thanks to its coastal location, rates of sea and fish consumption are high. Erzurum, on the other hand, is located at the easternmost point of Turkey (41.1 East). The city lies in mountainous terrain with an altitude of $1893 \mathrm{~m}$. The average temperature in the study period was $12.3^{\circ} \mathrm{C}$. Among women, Islamic covered clothing style and domestic life are common. Local cuisine typically does not contain seafood.

The present study was approved by the local ethical committee at Şifa University, written consent was obtained to participate, and the procedures followed were in accordance with the Helsinki Declaration of 1975 (revised in 2008). The study data were collected from Erzurum Şifa Hospital and Şifa University, Bornova Health Research and Application Hospital, between June 2012 and October 2012.

Vitamin D status was defined by serum levels of $25(\mathrm{OH}) \mathrm{D}_{3}$ as follows: severe vitamin D deficiency, $25(\mathrm{OH}) \mathrm{D}_{3} \leq 10 \mathrm{ng} / \mathrm{mL}(25$ $\mathrm{nmol} / \mathrm{L})$; mild vitamin D deficiency, $25(\mathrm{OH}) \mathrm{D}_{3}$ of $10-20 \mathrm{ng} / \mathrm{mL}$ (25-50 nmol/L); normal $\geq 20 \mathrm{ng} / \mathrm{mL}$ (50 nmol/L), and optimal status, $25(\mathrm{OH}) \mathrm{D}_{3} \geq 32 \mathrm{ng} / \mathrm{mL}(80 \mathrm{nmol} / \mathrm{L})$.

\section{Collection of the Study Data}

Voluntary women at 24-28 weeks of pregnancy attending routine antenatal review or glucose challenge tests were the source population. Subjects with diabetes mellitus, hypertension, chronic liver and renal disease, rheumatic disease, gastrointestinal diseases with malabsorption, and other chronic diseases, as well as subjects on chronic medical therapy were excluded. In total 687 participants, 387 participants in İzmir Bornova Health Research and Application Hospital and 245 participants in Erzurum Şifa Hospital; were founded suitable for study criteria in this period. Eligible women were questioned via a questionnaire form about their lifestyle, and blood samples were taken for $25(\mathrm{OH}) \mathrm{D}_{3}$ levels.

The questionnaire form offered to the participants included questions about annual income, educational level; parity; smoking; the frequency of exposure to sunlight; clothing style; using sunscreen; seaside holiday duration within the last 6 months; status of fish, milk, egg, and vitamin D-enriched food consumption; and status of vitamin D and multivitamin use. Occupational status of the pregnant women was also assessed. The frequency of exposure to sunlight was questioned in terms of number of days of exposure in a week, not less than 30 minutes. Covered clothing style was defined as clothing covering all body parts except for the hands and face. Consumption of a half-liter milk or milk product was considered adequate. Fruit juice, margarines, and breakfast brittles are fortified with vitamin D and widely used in Turkey. However vitamin D-fortified milk is not used in our country. Regular use of at least one of these products was questioned under the title of vitamin D-enriched food consumption.

Skin color of the participants was classified according to the Fitzpatrick Skin Color Scale. Starting from 1 point up to 6, a score was given to each subject.

Body mass index (BMI, weight $(\mathrm{kg}) /$ height $(\mathrm{m})^{2}$ ) was calculated by measuring the height and body weight simultaneously with blood collection.

$25(\mathrm{OH}) \mathrm{D}_{3}$ level may be affected by lifestyles, personal characteristics, and living place. We aimed that to create study groups with similar personal characteristics in both provinces to better understand the opportunity of lifestyles to affect vitamin D deficiency. For this reason, the study groups was defined as follows: a) skin color $<4$ according to Fitzpatrick Skin Color Scale, b) BMI $20-30 \mathrm{~kg} / \mathrm{m}^{2}$, c) parity $\leq 3$, d) educational level $\geq 8$ year, e) annual income $\geq \$ 4500, \mathrm{f}$ ) Caucasian ethnicity, and f) age 18-40. Afterwards, the study groups were created according to the questionnaires of participants. As a result, 208 pregnant were included in the study. Figure 1 represents a flowchart of the study design.

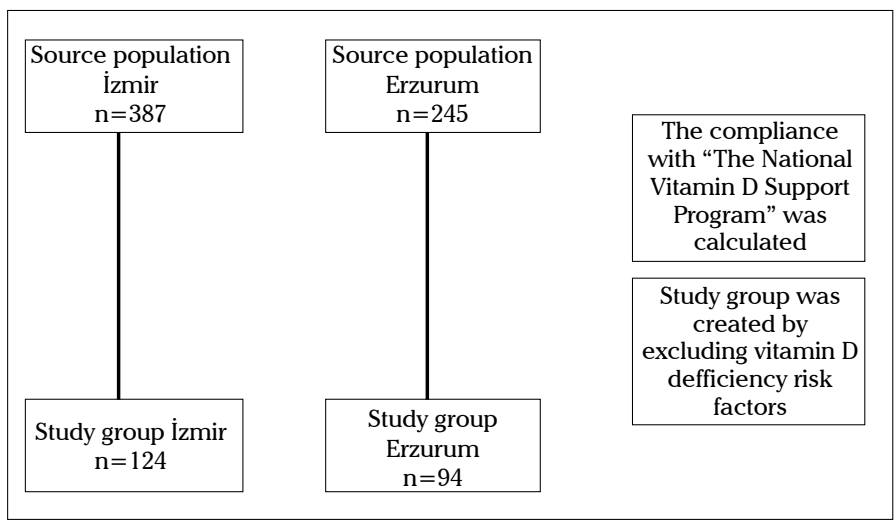

Figure 1. Flow chart of the study design 


\section{Collection of Blood Samples}

Blood samples collected in Erzurum were sent to İzmir at $-20^{\circ} \mathrm{C}$ under protection from sunlight. All laboratory analyses were performed in a single laboratory. $25(\mathrm{OH}) \mathrm{D}_{3}$ level was analyzed by ELISA (EUROIMMUN, D-23560 Lübeck, Seekamp 31, Germany) method.

\section{Statistical Analysis}

Statistical analysis was performed by using the SPSS (15.0) for Windows (SPSS Inc., Chicago, IL, USA). Categorical variables were analyzed by forming a crosstable for inter-group differences, and $\chi^{2}$ analysis was performed. For $25(\mathrm{OH}) \mathrm{D}_{3}$ level, t-test for comparison of 2 groups was used. Variables within a group were analyzed using ANOVA test. A significant ANOVA test result was further analyzed with Bonferroni test when the variance was homogenous and Dunnett T3 test when it was not. A 2-sided analysis of variance was done for $25(\mathrm{OH}) \mathrm{D}_{3}$ by considering the province and the variables. A logistic regression analysis was performed for predictor factors of vitamin D deficiency, with 2 separate analyses being performed by assuming threshold values of 20 and 32 . A p value less than 0.05 was considered statistically significant.

\section{Results}

In total, 387 participants in Bornova Health Research and Application Hospital and 245 participants in Erzurum Sifa Hospital were accepted for study. Usage of vitamin D in pregnancy in İzmir and Erzurum and compliance with "The National Vitamin D Support Program for Pregnancy" were calculated. Afterwards, study groups were created according to the personal characteristics of the participants. As a result, 124 pregnant women in İzmir and 94 pregnant women in Erzurum were included in the study.

The mean age was $28.4 \pm 4.5$ in the İzmir study group and $29.1 \pm 5.1$ in the Erzurum study group, the mean gestational week was $25.2 \pm 3.1$ in the İzmir study group and $26.1 \pm 5.4$ in the Erzurum study group, and BMI averaged 27.1 \pm 3.5 in İzmir and 26.6 \pm 3.3 in Erzurum, with no significant difference between the groups.

Table 1. Vitamin D usage in İzmir and Erzurum

\begin{tabular}{|l|c|c|c|}
\hline $\begin{array}{l}\text { Regular vitamin } \\
\text { D replacement* }\end{array}$ & $\begin{array}{c}\mathbf{1 2 0 0} \text { IU/day } \\
\text { (n, \%) }\end{array}$ & $\begin{array}{c}\mathbf{4 0 0} \text { IU/day } \\
\text { (n, \%) }\end{array}$ & $\begin{array}{c}\text { No vitamin D } \\
\text { replacement } \\
\text { (n, \%) }\end{array}$ \\
\hline İzmir (n=387) & $31(8 \%)$ & $325(83.9 \%)$ & $31(8 \%)$ \\
\hline Erzurum (n=245) & $80(32.6 \%)$ & $157(64 \%)$ & $8(3.2 \%)$ \\
\hline
\end{tabular}

Compliance with "The National Vitamin D Support Program" We found that $8 \%$ of pregnant women in İzmir and $32.6 \%$ of pregnant women in Erzurum took $1200 \mathrm{IU} /$ day vitamin $\mathrm{D}$, the recommended dose of The National Program, and $83.9 \%$ of pregnant women in İzmir and $64 \%$ of pregnant women in Erzurum used $400 \mathrm{IU} /$ day vitamin D (multivitamin). Furthermore, we observed that $8 \%$ of pregnant women in İzmir and $3.2 \%$ of pregnant women in Erzurum did not take vitamin D supplementation. Vitamin D usage in İzmir and Erzurum is given in Table 1.

\section{Serum 25(OH) $D_{3}$ Levels by Provinces}

$25(\mathrm{OH}) \mathrm{D}_{3}$ levels by provinces are given in Table 2. Severe vitamin D deficiency was present in $11.2 \%$ of the İzmir group and $17 \%$ of the Erzurum group. Mild vitamin D deficiency was present in $23.3 \%$ of the İzmir group and $58.5 \%$ of the Erzurum group. Normal vitamin D level rate ( $\geq 20 \mathrm{ng} / \mathrm{mL}$ ) was $65.3 \%$ in İzmir and $24.4 \%$ in Erzurum. However, 34\% of pregnant subjects from İzmir and only $1 \%$ of those from Erzurum had optimal 25(OH) $\mathrm{D}_{3}$ levels $\left(\geq 32 \mathrm{ng} / \mathrm{mL}\right.$ ). Average $25(\mathrm{OH}) \mathrm{D}_{3}$ level was $38 \mathrm{ng} / \mathrm{mL}$ $( \pm 3.6$ standard deviation (SD)) in İzmir and $16 \mathrm{ng} / \mathrm{mL}( \pm 5.8 \mathrm{SD})$ in Erzurum.

Factors Associated with Serum 25(OH) $\mathrm{D}_{3}$ Level

Effects of lifestyle factors on $25(\mathrm{OH}) \mathrm{D}_{3}$ level were separately assessed for İzmir and Erzurum. While uncovered clothing, fish consumption, a longer seaside holiday duration, and 1200 IU/day vitamin D replacement significantly increased $25(\mathrm{OH})$ $\mathrm{D}_{3}$ level in pregnant subjects living in İzmir, long holiday duration and $1200 \mathrm{IU} /$ day vitamin D replacement affected 25(OH) $\mathrm{D}_{3}$ in the Erzurum group. The effects of lifestyle factors on local $25(\mathrm{OH}) \mathrm{D}_{3}$ levels are summarized in Table 3.

Assuming the threshold level as $20 \mathrm{ng} / \mathrm{mL}$, logistic regression analysis showed that covered clothing style by 2.9 -fold, holiday duration less than 1 week by 23.5 -fold, vitamin $\mathrm{D}$ replacement less than 3 days a week and less than $1200 \mathrm{IU} /$ day by 6.2 -fold, consuming fish less than once a week by 1.6 -fold, and living in Erzurum by 38.3-fold were increased the risk of vitamin D deficiency. A threshold of $32 \mathrm{ng} / \mathrm{mL}$, on the other hand, made living in Erzurum the only effective factor that increased vitamin D deficiency risk by 33.5 -fold. The results of the multivariate logistic regression analysis are summarized in Tables 4 and 5 .

\section{Discussion}

Data from eastern and western parts of Turkey showed that even in summer and fall, the prevalence of vitamin D deficiency in pregnancy is high in our country, although the vitamin D defi-

Table 2. 25(OH)D $\mathrm{D}_{3}$ levels in İzmir and Erzurum

\begin{tabular}{|c|c|c|c|c|c|c|}
\hline $\begin{array}{l}25(\mathrm{OH}) \mathrm{D}_{3} \text { level } \\
(\mathrm{ng} / \mathrm{mL})\end{array}$ & $\begin{array}{l}\text { Severe deficiency } \\
(\leq 10 \mathrm{ng} / \mathrm{mL})\end{array}$ & $\begin{array}{c}\text { Mild deficiency } \\
(10-20 \mathrm{ng} / \mathrm{mL})\end{array}$ & $\begin{array}{l}\text { Normal level } \\
(\geq 20 \mathrm{ng} / \mathrm{mL})\end{array}$ & $\begin{array}{l}\text { Optimal level } \\
\text { ( } \geq 32 \mathrm{ng} / \mathrm{mL})\end{array}$ & $\begin{array}{l}\text { Average level } \\
\quad( \pm \text { SD) }\end{array}$ & $\begin{array}{c}\mathbf{p} \\
\text { value }\end{array}$ \\
\hline İzmir (n, \%) & $14(11.2)$ & 29 (23.3) & $81(65.3)$ & $38(34)$ & $38(3.6)$ & $<0.001$ \\
\hline Erzurum (n, \%) & $16(17)$ & $55(58.5)$ & $23(24.4)$ & $1(1)$ & $16(5.8)$ & \\
\hline
\end{tabular}


Table 3. Associations between lifestyle and $25(\mathrm{OH}) \mathrm{D}_{3}$ level

\begin{tabular}{|c|c|c|c|c|}
\hline $\begin{array}{l}\text { Predictor factors } \\
\text { 25(OH)D } D_{3} \text { level }\end{array}$ & $\begin{array}{l}25(\mathrm{OH}) \mathrm{D}_{3} \text { level } \\
\text { İzmir }(\mathrm{ng} / \mathrm{mL})\end{array}$ & p value & $\begin{array}{c}25(\mathrm{OH}) \mathrm{D}_{3} \text { level } \\
\text { Erzurum }(\mathrm{ng} / \mathrm{mL})\end{array}$ & p value \\
\hline \multicolumn{5}{|l|}{ State of employment } \\
\hline Employed & 22 & 0.08 & 15.8 & 0.9 \\
\hline Unemployed & 26.5 & & 16.2 & \\
\hline Clothing style & & 0.03 & & 0.4 \\
\hline Covered clothing & 24.5 & & 15 & \\
\hline Uncovered clothing & 31.6 & & 17.9 & \\
\hline Smoking & & 0.9 & & 0.7 \\
\hline Smokers & 29.2 & & 18.4 & \\
\hline Non-smokers & 28.1 & & 17.3 & \\
\hline \multicolumn{5}{|l|}{ Seaside holiday duration } \\
\hline$<1$ week/last 6 month & 15.4 & $<0.01$ & 13.8 & $<0.01$ \\
\hline$\geq 1$ week/last 6 month & 31.8 & & 20.8 & \\
\hline Sun exposure & & 0.5 & & 0.9 \\
\hline$\geq 3$ day/week & 27.1 & & 16.5 & \\
\hline$<3$ day/week & 28.2 & & 15 & \\
\hline Using sunscreen & & 0.2 & & 0.6 \\
\hline Sometimes & 30 & & 18.4 & \\
\hline Never & 26.9 & & 15.5 & \\
\hline Fish consumption & & 0.04 & & 0.1 \\
\hline$\geq 1$ day/week & 30.3 & & 17.9 & \\
\hline More rare & 23.2 & & 15.8 & \\
\hline Egg consumption & & 0.5 & & 0.4 \\
\hline$\geq 3$ day/week & 27.1 & & 15.7 & \\
\hline$<3$ day/week & 27.5 & & 16 & \\
\hline Vitamin D-enriched food consumption & & 0.6 & & 0.1 \\
\hline$\geq 3$ day/week & 27.2 & & 14.8 & \\
\hline$<3$ day/week & 29.3 & & 14.6 & \\
\hline Milk consumption & & 0.4 & & 0.5 \\
\hline$\geq 3$ day/week & 29.4 & & 15.8 & \\
\hline$<3$ day/week & 25.3 & & 17.1 & \\
\hline 1200 IU/day Vitamin D supplement & & 0.04 & & 0.03 \\
\hline$\geq 3$ day/week & 35.7 & & 21.9 & \\
\hline$<3$ day/week & 27.7 & & 14.1 & \\
\hline 400 IU/day Vitamin D supplement & & 0.07 & & 0.7 \\
\hline$\geq 3$ day/week & 29.7 & & 16.9 & \\
\hline$<3$ day/week & 24.1 & & 13.7 & \\
\hline
\end{tabular}

ciency prevalence was significantly lower in İzmir (76.3\% versus $27.8 \%)$. It would not be surprising to see much lower levels in winter. Hence, a study by Halicioglu et al. (12) that examined winter and spring levels of $25(\mathrm{OH}) \mathrm{D}_{3}$ in 256 pregnant women living in İzmir reported a vitamin D deficiency $(\leq 20 \mathrm{mg} / \mathrm{mL})$ prevalence of $90.3 \%$ and a normal level $(\geq 30 \mathrm{mg} / \mathrm{mL})$ in only $0.4 \%$. Other studies from Turkey have reported that pregnancyassociated vitamin D deficiency remains a commonly seen problem (13-17). However, to our knowledge, the present study is the only study that has compared the difference in vitamin $\mathrm{D}$ 
Table 4. Significant predictive factors for vitamin D deficiency

\begin{tabular}{|l|c|c|c|}
\hline $\begin{array}{l}\text { Significant predictive factors } \\
\text { for vitamin D deficiency } \\
\text { (threshold } \geq \mathbf{2 0} \mathbf{~ n g / m L )}\end{array}$ & Odds ratio & $\mathbf{9 5 \%}$ CI & p value \\
\hline $\begin{array}{l}\text { Living place } \\
\text { (Living in Izmir versus } \\
\text { living in Erzurum) }\end{array}$ & 38.3 & $1.1-1276$ & 0.04 \\
\hline $\begin{array}{l}\text { Clothing style } \\
\text { (uncovered versus } \\
\text { covered clothing) }\end{array}$ & 2.9 & $1.1-7.9$ & $<0.02$ \\
\hline $\begin{array}{l}\text { Seaside holiday duration } \\
\text { ( } \geq 1 \text { week/ last 6 month/ } \\
\text { versus }<1 \text { week/last } \\
\text { 6 month) }\end{array}$ & 23.5 & $7.0-78.1$ & $<0.001$ \\
\hline $\begin{array}{l}\text { 1200 IU/day Vitamin D } \\
\text { supplement ( } \geq 3 \text { day/week } \\
\text { versus consuming less than) }\end{array}$ & 6.2 & $1.2-4.1$ & $<0.02$ \\
\hline $\begin{array}{l}\text { Fish consumption } \\
\text { ( } \geq 1 \text { day/week versus } \\
\text { consuming less than) }\end{array}$ & 1.6 & $1.6-4.1$ & $<0.03$ \\
\hline
\end{tabular}

Multivariate logistic regression was made. The threshold was considered $\geq 20 \mathrm{ng} / \mathrm{mL}$

Table 5. Significant predictive factors for vitamin D deficiency

\begin{tabular}{|l|c|c|c|}
\hline $\begin{array}{l}\text { Significant predictive factors } \\
\text { for vitamin D deficiency } \\
\text { (the threshold } \geq \mathbf{3 2} \mathbf{~ n g / m L )}\end{array}$ & Odds ratio & $\mathbf{9 5 \%}$ CI & p value \\
\hline $\begin{array}{l}\text { Living place } \\
\text { (Living in Izmir versus } \\
\text { living in Erzurum) }\end{array}$ & 33.5 & $3.8-296$ & 0.02 \\
\hline
\end{tabular}

Multivariate logistic regression was made. The threshold was considered $\geq 32 \mathrm{ng} / \mathrm{mL}$

deficiency prevalence in pregnancy between regions of Turkey. Behavioral factors and personal characteristics can affect $25(\mathrm{OH}) \mathrm{D}_{3}$ level (9). We aimed to create study groups with similar personal characteristics in both provinces to better understand the lifestyle effects on vitamin D deficiency. In our study, we observed that clothing style, seaside holiday duration, consuming fish, and $1200 \mathrm{IU} /$ day vitamin D supplement affected $25(\mathrm{OH}) \mathrm{D}_{3}$ level.

The body surface area required for ideal $25(\mathrm{OH}) \mathrm{D}_{3}$ synthesis is not entirely known. In a study by Perampalam et al. (9), it was found that the critical body surface area required for sustaining an adequate $25(\mathrm{OH}) \mathrm{D}_{3}$ level was $>27 \%$ and that the body surface area exposed to sunlight was the main behavioral factor related to $25(\mathrm{OH}) \mathrm{D}_{3}$ level. In Islamic clothing (hands and face uncovered), $8 \%$ of the total body surface area remains uncovered.

Among the dietary sources, the only ones that seem to affect $25(\mathrm{OH}) \mathrm{D}_{3}$ synthesis are fish. However, $56 \%$ of the pregnant women in İzmir and $82 \%$ of those residing in Erzurum consumed fish less than once a week. Seafood is also a good source of omega-3 fatty acids, and it contains high-quality proteins (18). Promoting fish consumption in pregnant women may be reasonable with respect to $25(\mathrm{OH}) \mathrm{D}_{3}$ levels. In our study, we did not detect a relationship between vitamin D-enriched foods and $25(\mathrm{OH}) \mathrm{D}_{3}$ levels. This situation can be explained by the limited vitamin D-reinforced food in Turkey (15), whereas in a study by Charatcharoenwitthaya et al. (19), it was found that drinking vitamin-fortified milk affected $25(\mathrm{OH}) \mathrm{D}_{3}$ levels in pregnancy.

Surprisingly, although we found that seaside holiday duration affected $25(\mathrm{OH}) \mathrm{D}_{3}$ level in both İzmir and Erzurum, we did not detect any relationship between sunlight exposure duration and $25(\mathrm{OH}) \mathrm{D}_{3}$ levels. This situation can be explained by factors, such as exposure to sunlight at times other than noon, covering clothing style, and use of sunscreen. Using sunscreen prevents vitamin D synthesis, disallowing ultraviolet B (UVB) rays to penetrate the skin. Our study may not have had the ability to detect effects of using sunscreen on vitamin D levels, since the rates of sunscreen use were as low as $11 \%$ and $20 \%$ in the groups. Additionally, since UVB rays have a short wavelength, $25(\mathrm{OH}) \mathrm{D}_{3}$ synthesis reaches the top at noon, when the sunlight hits the earth at a perpendicular angle. Even 30 minutes of sunbathing without using sunscreen at noon may lead to synthesis of $25(\mathrm{OH}) \mathrm{D}_{3}$ at an amount of $15-20,000 \mathrm{IU}(20,21)$. Therefore, having adequate sun exposure may not mean having adequate $25(\mathrm{OH}) \mathrm{D}_{3}$ levels.

In our study, we found that a vitamin $\mathrm{D}$ dose of $400 \mathrm{IU} / \mathrm{day}$ in multivitamins did not affect $25(\mathrm{OH}) \mathrm{D}_{3}$ level. On the other hand, $25(\mathrm{OH}) \mathrm{D}_{3}$ levels increased in women using a dose of $1200 \mathrm{IU} /$ day. There is no consensus with regard to vitamin $\mathrm{D}$ replacement to sustain a normal $25(\mathrm{OH}) \mathrm{D}_{3}$ level for healthy pregnancy. The National Health Institute recommends $400 \mathrm{IU} /$ day, and the World Health Organization recommends $200 \mathrm{IU} /$ day vitamin D supplementation for pregnant women (22). Recent studies have shown that the official vitamin D dosing recommendations are far from meeting the demands of pregnancy, and $25(\mathrm{OH}) \mathrm{D}_{3}$ levels may be more effectively boosted with doses as high as 1600, 2000, and $4000 \mathrm{IU} /$ day, without increasing side effects $(23,24)$. Wagner et al. (25) reported that serum $25(\mathrm{OH}) \mathrm{D}_{3}$ levels did not change significantly until after vitamin D supplementation exceeded $1000 \mathrm{IU} /$ day. The dose that leads to vitamin D intoxication is not precisely known; however, vitamin $\mathrm{D}$ intoxication can be considered an extremely rare and exaggerated condition. The National Health Institution has reported that 4000 IU/day is the upper safe limit for pregnant women (22). No side effects have been reported in volunteer non-pregnant women at doses of $10,000 \mathrm{IU} /$ day (26). It seems that the recommended supplementation doses will increase as the number of randomized controlled studies on this subject increases.

In Turkey, until May 2011, a health policy on vitamin D prophylaxis for pregnant women did not exist; thus, the vitamin D supplements prescribed for pregnant women were limited to low doses (200-400 IU), amounts generally included in commercial multivitamin preparations. Since 2011, the Turkish Ministry of Health has recommended vitamin D supplementation to all pregnant women at a dose of $1200 \mathrm{IU} /$ day starting from 12 weeks of pregnancy (27). However, $8 \%$ of the İzmir group and $32.6 \%$ of the Erzurum group were taking vitamin D at recommended doses in our study groups. Our study found that the 
compliance "The National Vitamin D Support Program" is poor. In our study, we found that the threshold was $32 \mathrm{ng} / \mathrm{mL}$ instead of $20 \mathrm{ng} / \mathrm{mL}$ for normal levels of $25(\mathrm{OH}) \mathrm{D}_{3}$, the living place was the only effective factor for vitamin $\mathrm{D}$ deficiency, and lifestyle did not affect $25(\mathrm{OH}) \mathrm{D}_{3}$ level. Furthermore, only one-third of pregnant women living İzmir had optimal $25(\mathrm{OH}) \mathrm{D}_{3}$ levels, even in summer and fall. For this reason, it seems reasonable to taking all pregnant subjects irrespective of region and season "The National Vitamin D Support Program." In our study, the average $25(\mathrm{OH}) \mathrm{D}_{3}$ level of pregnant women who took $1200 \mathrm{IU} /$ day vitamin D in Erzurum was $21.9 \mathrm{ng} / \mathrm{mL}$. It is suggested that a dose of $1200 \mathrm{IU} /$ day vitamin D during the winter months in Erzurum may not be sufficient. The dose of vitamin $\mathrm{D}$ may have to be increased, or pregnant women living in cold regions may be screened for vitamin D levels.

There are some limitations of our study. One of them is that the study could not reflect seasonal differences, because the study was only conducted in the summer and fall, and the other is that we created study groups with similar personal characteristics in both provinces to better understand the lifestyle effects on vitamin D deficiency. Consequently, the study groups were small.

In conclusion, prevalence of vitamin D deficiency in pregnancy is high in Turkey even, in the sunny season. Behavioral factors are more effective on $25(\mathrm{OH}) \mathrm{D}_{3}$ levels in pregnancy in sundrenched regions. Living in high-altitude cold regions seems to be the most powerful risk factor for vitamin D deficiency. Even in sun-drenched regions, only one-third of pregnant subjects had ideal $25(\mathrm{OH}) \mathrm{D}_{3}$ levels. Vitamin $\mathrm{D}$ supplementation is a cheap, safe, and effective means to fight vitamin D deficiency. It is recommended to increase compliance with "The National Vitamin D Support Program" at follow-up of all pregnant women, irrespective of region and season. The reasons of poor compliance with this program should be investigated. For more precise recommendations, more randomized, controlled studies on vitamin D deficiency in pregnancy are needed.

Ethics Committee Approval: Ethics committee approval was received for this study from the ethics committee of Sifa University.

Informed Consent: Written informed consent was obtained from patients who participated in this study.

Peer-review: Externally peer-reviewed.

Author contributions: Concept - E.B.G., S.G.; Design - E.B.G., S.G.; Supervision - M.K., S.G.; Resource - E.B.G., G.A.T., S.T.; Materials - S.T., A.G., G.C.; Data Collection\&/or Processing E.B.G., A.G., G.C.; Analysis\&/or Interpretation - M.G.; Literature Search - M.G.; Writing - E.B.G., S.G.; Critical Reviews - M.K., S.G.

Acknowledgements: We are grateful for the assistance during the study period to hospital management of Erzurum Sifa Hospital.

Conflict of Interest: No conflict of interest was declared by the authors.

Financial Disclosure: The authors declared that this study has received no financial support.

\section{References}

1. Norman AW. From vitamin D to hormone D: Fundamentals of the vitamin D endocrine system essential for good health. Am J Clin Nutr 2008; 88: 491-9.

2. Bikle D. Nonclassic actions of vitamin D. J Clin Endocrinol Metab 2009; 94: 26-34. [CrossRef]

3. Kovacs C. Vitamin D in pregnancy and lactation: Maternal, fetal, and neonatal outcomes from human and animal studies. Am J Clin Nutr 2008; 88: 520-8.

4. Hollis BW, Wagner CL. Assessment of dietary vitamin D requirements during pregnancy and lactation. Am J Clin Nutr 2004; 79: 717-26.

5. Holick MF, Chen TC. Vitamin D deficiency: A worldwide problem with health consequences. Am J Clin Nutr 2008; 87: 1080-6.

6. Litonjua AA, Weiss ST. Is vitamin D deficiency to blame for the asthma epidemic? J Allergy Clin Immunol 2007; 120: 1031-5. [CrossRef]

7. Stene LC, Ulriksen J, Magnus P, Joner G. Use of cod liver oil during pregnancy associated with lower risk of Type I diabetes in the offspring. Diabetologia 2000; 43: 1093-8. [CrossRef]

8. McGrath JJ, Welham JL. Season of birth and schizophrenia: A systematic review and metaanalysis of data from the Southern Hemisphere. Schizophr Res 1999; 35: 237-42.[CrossRef]

9. Perampalam S, Ganda K, Chow KA, Opıe N, Hickman PE, Shadbolt $\mathrm{B}$, et al. Vitamin D status and its predictive factors in pregnancy in 2 Australian populations. Aust N Z J Obstet Gynaecol 2011; 51: 353-9. [CrossRef]

10. Feleke Y, Abdulkadir J, Mshana R, Mekbib TA, Brunvand L,Berg JP. Low levels of serum calcidiol in an African population compared to a North European population. Eur J Endocrinol 1999; 141: 358-60. [CrossRef]

11. Farrant HJ, Krishnaveni GV, Hill JC, Boucher BJ, Fisher DJ, Noonan $\mathrm{K}$. Vitamin D insufficiency is common in Indian mothers but is not associated with gestational diabetes or variation in newborn size. Eur J Clin Nutr 2009; 63: 646-52. [CrossRef]

12. Halicioglu O, Aksit S, Koc F, Akman SA, Albudak E, Yaprak I, et al. Vitamin D deficiency in pregnant women and their neonates in spring time in western Turkey. Paediatr Perinat Epidemiol 2012; 26: 53-60. [CrossRef]

13. Ustuner I, Keskin HL, Tas EE, Neselioglu S, Sengul O, Avsar AF. Maternal serum 25(OH)D levels in the third trimester of pregnancy during the winter season. J Matern Fetal Neonatal Med 2011; 24: 1421-6. [CrossRef]

14. Hatun S, Islam O, Cizmecioglu F, Kara B, Babaoglu K, Berk F. Subclinical vitamin D deficiency is increased in adolescent girls who wear concealing clothing. J Nutr 2005; 135: 218-22.

15. Alagöl F, Shihadeh Y, Boztepe H, Tanakol R, Yarman S, Azizlerli H, Sandalci O. Sunlight exposure and vitamin D deficiency in Turkish women. J Endocrinol Invest 2000; 23: 173-7. [CrossRef]

16. Pehlivan I, Hatun S, Aydoğan M, Babaoğlu K, Gökalp AS. Maternal vitamin $\mathrm{D}$ deficiency and vitamin $\mathrm{D}$ supplementation in healthy infants. Turk J Pediatr 2003; 45: 315-20.

17. Ergür AT, Berberoğlu M, Atasay B, Şıklar Z, Bilir P, Arsan S, et al. Vitamin D deficiency in Turkish mothers and their neonates and in women of reproductive age. J Clin Res Pediatr Endocrinol 2009; 1: 266-9. [CrossRef]

18. Canda MT, Sezer O, Demir N. An audit of seafood consumption awareness during pregnancy and its association with maternal and fetal outcomes in a Turkish population. J Obstet Gynecol 2011; 31 : 293-7. [CrossRef] 
19. Charatcharoenwitthaya N, Nanthakomon T, Somprasit C, Chanthasenanont A, Chailurkit LO, Pattaraarchachai J, Ongphiphadhanakul B. Maternal vitamin D status, its associated factors and the course of pregnancy in Thai women. Clin Endocrinol (Oxf) 2013; 78: 126-33. [CrossRef]

20. Krause R, Buhring M, Hopfenmuller W. Ultraviolet B and blood pressure. Lancet 1998; 352: 709-10. [CrossRef]

21. Holick MF. Environmental factors that influence the cutaneous production of vitamin D. Am J Clin Nutr 1995; 61: 638-45.

22. Doets EL, de Wit LS, Dhonukshe-Rutten RA, Cavelaars AE, Raats $\mathrm{MM}$, et al. Current micronutrient recommendations in Europe: Towards understanding their differences and similarities. Eur $\mathrm{J}$ Nutr 2008; 47: 17-40. [CrossRef]

23. Wagner CL, McNeil R, Hamilton SA, Winkler J, Rodriguez Cook C, Warner $\mathrm{G}$, et al. A randomized trial of vitamin D supplementation in 2 community health center networks in South Carolina. Am J Obstet Gynecol 2013; 208: 137.e1-13.

24. Hollis BW, Wagner CL. Nutritional vitamin D status during pregnancy: Reasons for concern. CMAJ 2006; 174: 1287-90. [CrossRef]

25. Wagner CL, Hulsey TC, Fanning D, Ebeling M, HollisBW. High-dose vitaminD3 upplementation in a cohort of breastfeeding mother sand thei infants: a 6-month follow-up pilot study. Breastfeed Med 2006; 1: 59-70. [CrossRef]

26. Vieth, R. Vitamin D supplementation, 25-hydroxyvitamin D concentrations, and safety. Am J Clin Nutr 1999; 69: 842-56.

27. Gur G, Abacı A, Koksoy AY, Anık A, Catlı G, Kıslal FM, et al. Incidence of maternal Vitamin D deficiency in a region of Ankara, Turkey: a preliminary study. Turk J Med Sci 2014; 44: doi:10.3906/ sag-1304-107. [CrossRef] 